\title{
PENGARUH MULTIMEDIA INTERAKTIF, GAYA BELAJAR DAN KONSEP DIRI TERHADAP PRESTASI BELAJAR MATEMATIKA
}

\author{
M. Ardiansyah \\ Program studi Teknik Informatika, Universitas Indraprasta PGRI \\ Email: m.ardiansyah_unindra@yahoo.co.id
}

\begin{abstract}
Abstrak
Tujuan Penelitian ini adalah untuk mencari pengaruh multimedia interaktif, gaya belajar, dan konsep diri terhadap prestasi belajar matematika dengan menggunakan Anova tiga jalur. Metode penelitian yang digunakan adalah survey. Instrumen yang digunakan adalah kuesioner dan tes. Jumlah sampel yang digunakan sebanyak 90 responden, masing-masing 30 siswa dari SMP PGRI 32, SMP Ma`arif, dan SMP Fatahilah Jakarta tahun ajaran 2018/2019, dengan menggunakan teknik purposive sampling. Hasil perhitungan menunjukkan bahwa 1) Multimedia interaktif berpengaruh positif dan signifikan terhadap gaya belajar, 2) Multimeda interaktif berpengaruh positif dan signifikan terhadap konsep diri, 3) Gaya belajar tidak berpengaruh signifikan terhadap konsep diri, 4) Gaya belajar berpengaruh positif dan signifikan terhadap prestasi belajar matematika, 5) Konsep diri berpengaruh positif dan signifikan terhadap prestasi belajar matematika, 6) Multimedia interaktif berpengaruh tidak langsung terhadap prestasi belajar matematika melalui konsep diri, 7) Multimedia interaktif berpengaruh tidak langsung dan signifikan terhadap prestasi belajar matematika melalui gaya belajar, 8) Gaya belajar berpengaruh tidak langsung terhadap prestasi belajar matematika melalui konsep diri, 9) Multimedia interaktif tidak berpengaruh positif dan signifikan terhadap konsep diri melalui prestasi belajar matematika.
\end{abstract}

Kata Kunci : Multimedia interaktif, gaya belajar, konsep diri, prestasi belajar matematika

\begin{abstract}
The purpose of this study is to find the effects of interactive multimedia, learning styles, and selfconcept mathematics learning achievement using the three ways ANOVA. The research method used was a survey. The instruments were questionnaires and tests. The samples used were 90 respondents, 30 students each from SMP PGRI 32, SMP Ma'arif, and SMP Fatahilah Jakarta for the 2018/2019 school year using a purposive sampling technique. The results of the calculations showed that 1) interactive multimedia has a positive and significant effect on learning styles, 2) interactive multimedia has a positive and significant effect on self-concept, 3) learning style does not have a significant effect on self-concept, 4) learning style has a positive and significant effect on learning achievement mathematics, 5) Self-concept has a positive and significant effect on mathematics learning achievement, 6) Interactive multimedia has an indirect effect on mathematics learning achievement through self-concept, 7) Interactive multimedia has an indirect and significant effect on mathematics learning achievement through learning styles, 8) Learning style does not have an indirect effect on mathematics learning achievement through self-concept, 9) Interactive multimedia does not have a positive and significant effect on self-concept through mathematics learning achievement.
\end{abstract}

Keywords : Interactive multimedia, learning styles, self concept, mathematics learning achievement

\section{PENDAHULUAN}

Perkembangan yang terjadi pada peserta didik sangat berguna bagi pribadinya maupun orang lain, hal ini biasa disebut sebagai sesuatu yang sangat bermanfaat dan dapat menunjukkan kualitas hidup seseorang yang merupakan refleksi atau gambaran dari prestasi belajar peserta didik. Prestasi belajar yang mengacu pada pencapaian taksonomi pendidikan yang mencakup berbagai aspek kognitif, afektif, dan psikomotorik [1]. Salah satu upaya yang dapat menjadikan seseorang berprestasi adalah melakukan kegiatan yang berkesinambungan dan berkelanjutan. Prestasi merupakan hasil dari usaha peserta didik dalam mengembangkan bakat secara terus menerus. Hasil belajar merupakan sebuah prestasi belajar yang diperoleh peserta didik yang dapat diukur dari berapa 
besarnya nilai yang diperoleh peserta didik setelah mengerjakan beberapa soal yang diberikan oleh pendidik pada saat evaluasi dilaksanakan [2]. Matematika merupakan ilmu pasti yang sistematis dan bersifat artificial. Pembelajaran matematika seharusnya dipelajari dengan sistematis sesuai urutannya serta disajikan dengan cara yang jelas dan harus disesuaikan dengan perkembangan kognitif peserta didik serta kemampuan prasyarat yang dimilikinya [3].

Prestasi belajar matematika peserta didik dalam proses pembelajaran juga tergantung dari berbagai subjek dan objek dari pembelajaran yaitu salah satunya adalah dengan pembelajaran matematika dengan menggunakan multimedia interaktif. Soal matematika yang disajikan dalam bentuk slide dengan media multimedia dalam proses pembelajaran yang berkembang pada umumnya tidak sejalan dengan teori kognitif multimedia pembelajaran.

Keberhasilan pembelajaran dengan multimedia bergantung dari desain multimedia yang pendidik terapkan. Pembelajaran akan memberikan hasil yang lebih maksimal jika didesain sesuai cara peserta didik belajar [4]. Peserta didik sebagai pengguna multimedia pembelajaran harus melakukan interaksi yang intensif dalam tercapainya tujuan pembelajaran. Interaksi peserta didik dipengaruhi oleh banyak faktor, salah satunya adalah kecenderungan dalam gaya belajar siswa.

Gaya belajar pada seorang peserta didik secara umum ada 3, yaitu gaya belajar visual, auditory, dan kinestetik. Ketiga tipe dari gaya belajar pada peserta didik ini mempunyai pendekatan yang sangat berbeda sesuai dengan sikap dan karakter yang dimiliki oleh peserta didik. Sama halnya pada pembelajaran, tipe gaya belajar peserta didik [5] tentunya juga berbeda-beda sesuai kemampuan dan kompetensi dari peserta didik dalam mengolah materi-materi matematika yang cukup sulit dan cakupannya luas.

Tipe gaya belajar peserta didik dalam satu kelas saja sudah sangat terlihat, ada beberapa peserta didik yang senang mencatat, ada peserta didik yang senang mendengarkan penjelasan guru, namun ada juga peserta didik yang senang berhitung matematika. Perbedaan gaya belajar pada peserta didik ini dapat mengakibatkan kelas kurang kondusif dalam pembelajaran [6]. Ketidaksesuaian faktor-faktor tersebut mengisyaratkan bahwa gaya belajar dapat mempengaruhi prestasi belajar matematika peserta didik.

Konsep diri merupakan faktor penting yang harus diperhatikan oleh setiap pendidik di jenjang manapun mereka berada. Hal ini senada dengan pernyataan yang menyatakan bahwa konsep diri adalah gambaran yang ada pada setiap diri individu yang berisikan tentang bagaimana individu melihat bagaimana dirinya sendiri sebagai pribadi yang disebut dengan pengetahuan diri, bagaimana individu merasa atas dirinya yang merupakan penilaian diri sendiri [7]. Seseorang yang mempunyai konsep diri yang positif dengan mudah dapat meraih prestasi pada mata pelajaran matematika.

Pengajaran dengan multimedia interaktif, gaya belajar dan konsep diri peserta didik yang dicapai melalui proses belajar matematika akan dapat diukur seberapa jauh kinerjanya yang disebut prestasi belajar. Bidang studi matematika merupakan salah satu bidang studi yang memerlukan kemampuan kognitif dari peserta didik, dimana pelajaran matematika adalah suatu abstraksi, generalisasi, yang harus dipelajari dari konsep yang telah tumbuh lama dari generasi ke generasi. 
Dari uraian di atas, peneliti merasa tertarik untuk meneliti seberapa besar pengaruh antara multimedia interaktif, gaya belajar, dan konsep diri terhadap prestasi belajar matematika peserta didik sesuai dengan metode analisis yang digunakan. Dari hasil penelitian ini diharapkan guru dapat mengajar menggunakan media multimedia interaktif sehingga pembelajaran tidak monoton pada penjelasan guru yang dapat membuat peserta didik merasa bosan dan jenuh. Selain itu, guru hendaknya lebih memperhatikan siswa tentang bagaimana gaya belajar dan konsep diri yang dibutuhkan sehingga dapat tercipta suasana pembelajaran dua arah yang lebih baik yang dapat meningkatkan prestasi belajar matematika siswa. Dalam mempelajari matematika memerlukan pengajaran yang berbasis multimedia, banyak pengulangan, gaya belajar yang efektif guna mengingat rumus matematika, dan konsep diri yang ada dalam diri peserta didik sebagai dasar penting dalam meningkatkan prestasi dalam pembelajaran matematika.

\section{METODE}

Penelitian ini menggunakan metode survey dan analisis yang digunakan dalam menguji hipotesis adalah analisis varians (ANAVA) tiga jalur. Ada empat variabel yang diteliti yaitu variabel bebas terdiri dari multimedia interaktif, gaya belajar dan konsep diri sedangkan variabel terikat adalah prestasi belajar matematika.

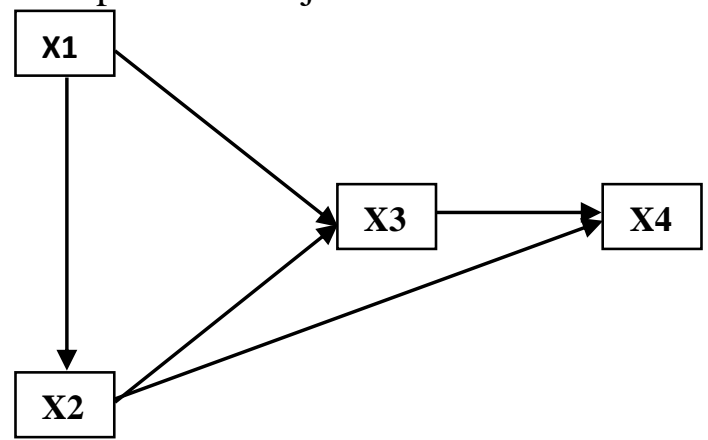

Gambar 1. Desain Penelitian

Keterangan:

$X_{1}$ : Multimedia interaktif

$X_{2}$ : Gaya belajar
$X_{3}: \quad$ Konsep diri

$X_{4}$ : Prestasi belajar matematika

Populasi target dalam penelitian ini adalah seluruh siswa SMP DKI Jakarta sedangkan Populasi terjangkau dalam penelitian ini adalah peserta didik SMP Jakarta Barat kec. Grogol Petamburan tahun ajaran 2018/2019 yaitu SMP PGRI 32 Jakarta, SMP Ma`arif Jakarta dan SMP Fatahilah Jakarta. Jumlah peserta didik yang dijadikan sampel yaitu masing-masing 30 peserta didik dari tiap sekolah, sehingga total peserta didik yang akan dijadikan responden sebanyak 90 orang.

Tabel 1. Sumber Data

\begin{tabular}{lcc}
\hline \multicolumn{1}{c}{ Variabel } & $\begin{array}{c}\text { Sumber } \\
\text { Data }\end{array}$ & $\begin{array}{c}\text { Teknik } \\
\text { Pengum- } \\
\text { pulan Data }\end{array}$ \\
\hline $\begin{array}{l}\text { Multimedia interaktif } \\
\text { Gaya belajar }\end{array}$ & Siswa & Angket \\
Konsep diri & Siswa & Angket \\
$\begin{array}{l}\text { Prestasi belajar } \\
\text { matematika }\end{array}$ & Siswa & Angket \\
\hline
\end{tabular}

\section{HASIL DAN PEMBAHASAN}

Proses pengujian hipotesis dilakukan dengan menggunakan analisis jalur, yaitu mencari koefisien pengaruh antara variabel yang satu terhadap variabel yang lain, baik secara langsung maupun tidak langsung. Proses penghitungan ini dilakukan dengan bantuan program SPSS 22.0, khususnya menggunakan analisis regresi setelah data dikonversi menjadi skor baku.

Persamaan untuk mencari koefisien jalur sebagai berikut:

$$
\begin{aligned}
& r_{12}=P_{21} \\
& r_{13}=P_{31}+P_{32} r_{21} \\
& r_{23}=P_{31} r_{12}+P_{32} \\
& r_{14}=P_{41}+P_{42} r_{21}+P_{43} r_{31} \\
& r_{24}=P_{41} r_{12}+P_{42}+P_{43} r_{32} \\
& r_{34}=P_{41} r_{31}+P_{42} r_{32}+P_{43}
\end{aligned}
$$

Dari hasil perhitungan menggunakan program SPSS 22.0 diperoleh hasil berikut: 
Tabel 2. Dependent Variable: Konsep Diri

Coefficients $^{a}$

\begin{tabular}{lrrcrr}
\hline \multicolumn{1}{c}{ Model } & $\begin{array}{c}\text { Unstandardized Coefficients } \\
\text { B }\end{array}$ & $\begin{array}{c}\text { Standardized Coefficients } \\
\text { Beta }\end{array}$ & $t$ & Sig. \\
\hline $\begin{array}{l}\text { (Constant) } \\
\begin{array}{l}\text { Zscore: } \\
\text { Multimedia } \\
\text { interaktif }\end{array}\end{array}$ & $1.21 \mathrm{E}-15$ & 8,23 & & 3,437 &, 000 \\
$\begin{array}{l}\text { Zscore: } \\
\text { Gaya belajar }\end{array}$ &,- 012 &, 078 & $\mathrm{P}_{31}=-, 009$ &,- 104 &, 425 \\
\hline
\end{tabular}

Tabel 3. Dependent Variable: Gaya Belajar

Coefficients $^{\mathbf{a}}$

\begin{tabular}{|c|c|c|c|c|c|}
\hline Model & $\begin{array}{c}\text { Unstandardi } \\
B\end{array}$ & $\begin{array}{l}\text { Coefficients } \\
\text { Std. Error }\end{array}$ & $\begin{array}{c}\text { Standardized Coefficients } \\
\text { Beta }\end{array}$ & $t$ & Sig. \\
\hline (Constant) & $-1.024 \mathrm{E}$ & 031 & & ,000 & 1,000 \\
\hline $\begin{array}{l}\text { Zscore: } \\
\text { Multimedia } \\
\text { interaktif }\end{array}$ & 203 & ,031 & $P_{21}=, 203$ & 3,471 & ,000 \\
\hline
\end{tabular}

Tabel 4. Dependent Variable: Zscore: Prestasi belajar matematika Coefficients $^{a}$

\begin{tabular}{|c|c|c|c|c|c|}
\hline \multirow[t]{2}{*}{ Model } & \multirow{2}{*}{$\begin{array}{c}\text { Unstandardized } \\
\text { Coefficients } \\
B\end{array}$} & \multicolumn{2}{|c|}{ Standardized Coefficients } & \multirow[b]{2}{*}{$t$} & \multirow[b]{2}{*}{ Sig. } \\
\hline & & Std. Error & Beta & & \\
\hline (Constant) & $-1.0 \mathrm{E}-15$ &, 042 & & 000 & 1,000 \\
\hline $\begin{array}{l}\text { Zscore: } \\
\text { Multimedia interaktif }\end{array}$ & , 149 &, 056 &, 149 & 2,629 & 001, \\
\hline $\begin{array}{l}\text { Zscore: } \\
\text { Gaya Belajar }\end{array}$ & ,326 & ,053, & ,326 & 4,591 & ,000, \\
\hline $\begin{array}{l}\text { Zscore: } \\
\text { Konsep Diri }\end{array}$ &,- 103 & 046, &,- 103 & $-1,018$ & ,003 \\
\hline
\end{tabular}

Dari keseluruhan hasil perhitungan di atas diperoleh diagram jalur sebagai berikut:

$P_{21}=0,203, P_{31}=0,103, P_{32}=\quad-0,010$, $P_{41}=-0,103, P_{42}=0,326, P_{43}=0,149$.

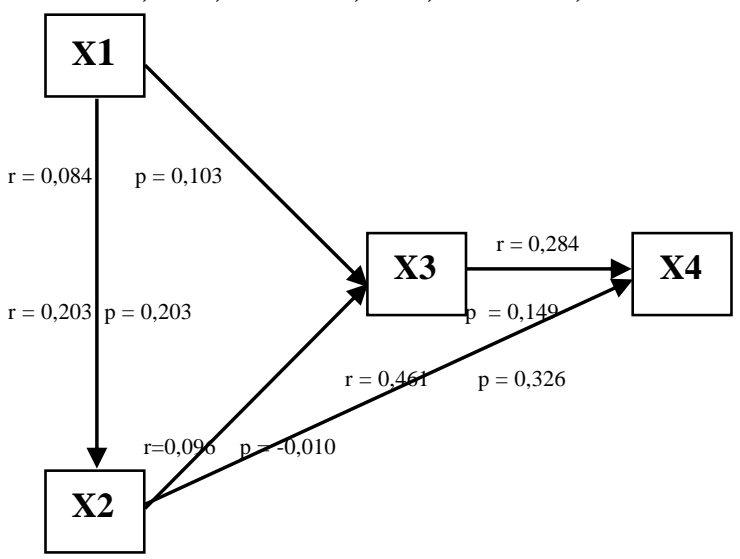

Gambar 2. Hasil Perhitungan Diagram Jalur

\section{Uji Hipotesis 1}

Korelasi antara multimedia interaktif dan gaya belajar adalah 0,203 ; koefisien jalur $\left(P_{21}\right)$ sebesar 0,203; dan thitung $=3,471>$ 0,207 dan sig $0,000<0,05$; sehingga disimpulkan: Kreativitas dapat dilakukan oleh guru agar dapat mengembangkan pembelajaran matematika, yaitu dengan menggunakan media pembelajaran yang efektif dan menyenangkan, sehingga siswa mudah untuk memahami pembelajaran. Penggunaan multimedia interaktif dalam proses pembelajaran dapat memperoleh gaya belajar siswa dengan maksimal. Salah satu media yang dapat digunakan guru dalam pembelajaran adalah dengan menggunakan multimedia interaktif yang dapat berperan sebagai media yang inovatif 
bagi siswa dalam mengkombinasikan gaya belajar siswa [8].

\section{Uji Hipotesis 2}

Koefisien korelasi antara multimedia interaktif dan konsep diri adalah 0,084; koefisien jalur $\left(P_{31}\right)$ sebesar 0,103 dan $t_{\text {thitung }}=2,427>0,207$ dan sig 0,425 > 0,05; sehingga dapat disimpulkan: Multimedia interaktif dapat berperan sebagai media yang efektif bagi siswa sebagai penyampai informasi materi kepada siswa. Pembelajaran matematika dengan media multimedia interaktif, tidak serta merta membuat konsep diri peserta didik mengalami peningkatan signifikan dalam proses belajar matematika [9].

\section{Uji Hipotesis 3}

Koefisien korelasi antara gaya belajar dan Konsep diri adalah 0,203; koefisien jalur $\left(P_{32}\right)$ sebesar -0,010; dan thitung $=-0,104<$ 0,207 dan sig 0,425 >0,05; sehingga dapat disimpulkan: Gaya belajar siswa perlu diperhatikan untuk menunjang potensi siswa dengan baik. Setiap siswa memiliki gaya belajar masing-masing. Seorang siswa juga harus memahami gaya belajarnya. Hal ini tentunya tergantung pada faktor yang konsep diri pada siswa itu sendiri sehingga siswa mampu beradaptasi pada pelajaran matematika [10].

\section{Uji Hipotesis 4}

Koefisien korelasi antara gaya belajar dan prestasi belajar matematika adalah 0,461 ; koefisien jalur $\left(P_{42}\right)$ sebesar 0,235 dan thitung $=4,591>0,207$ dan sig $0,000<0,05$; sehingga dapat disimpulkan: Gaya belajar merupakan cara termudah yang dimiliki oleh individu dalam mengatur, dan mengolah informasi yang diterimanya. Gaya belajar yang sesuai adalah kunci keberhasilan siswa dalam melakukan proses belajar matematika. Dengan menyadari hal ini, siswa mampu menyerap dan mengolah informasi dan menjadikan belajar lebih mudah dengan gaya belajar siswa sendiri, sehingga nantinya dapat meningkatkan prestasi belajar matematika [11]. Gaya belajar memberikan sebuah efek yang sangat signifikan terhadap prestasi belajar matematika [12].

\section{Uji Hipotesis 5}

Koefisien korelasi antara Konsep diri dan prestasi belajar matematika adalah 0,284 dan koefisien jalur $\left(P_{43}\right)$ sebesar 0,149 $t_{\text {hitung }}=2,629>0,207$ dan sig 0,001 < 0,05; sehingga disimpulkan: Konsep berfungsi sebagai pondasi mencapai keberhasilan dalam pembelajaran matematika. Konsep diri juga berperan sebagai penentu arah dalam bertindak. Siswa dengan konsep diri yang positif cenderung bertindak lebih positif dalam belajar, tugas yang diberikan guru akan diselesaikan dengan penuh tanggung jawab dan hambatan belajar ia jadikan sebagai tantangan, sehingga dapat meraih prestasi belajar matematika [13]. Penelitian ini sesuai dengan penelitian yang menyatakan bahwa terdapat pengaruh konsep diri dan kebiasaan belajar terhadap hasil belajar matematika [14].

\section{Uji Hipotesis 6}

Koefisien korelasi antara multimedia interaktif dan Konsep diri adalah 0,084 dan koefisien pengaruh $\left(P_{31}\right)$ sebesar 0,103; serta koefisien korelasi antara Konsep diri dan prestasi belajar matematika adalah 0,231 dan koefisien pengaruh $\left(P_{43}\right)$ sebesar 0,$149 ;$ thitung $=3,471>0,207$ dan sig 0,001 $<0,05$. Jadi didapat koefisien: $P_{31} \cdot P_{43}=$ $(0,103)(0,149)=0,015$. Dapat disimpulkan bahwa: Pengajaran dengan multimedia interaktif dalam proses belajar matematika akan dapat diukur seberapa jauh kinerjanya. Kinerja ini yang disebut prestasi belajar yang dapat dinilai dengan ujian tertulis dan ujian lisan. Konsep diri yang dimiliki seseorang akan turut menentukan bagaimana ia menerima, merasakan dan merespon pembelajaran. Seseorang yang berpikir bahwa dirinya kurang baik maka ia menganggap remeh 
dirinya serta membayangkan kegagalan di setiap usaha yang akan dilakukan. Prestasi belajar matematika siswa yang belajar menggunakan multimedia interaktif lebih baik dibandingkan siswa yang belajar konvensional sehingga hal ini dapat dinetralisir oleh konsep diri yang berada pada diri setiap siswa [15].

\section{Uji Hipotesis 7}

Koefisien korelasi antara multimedia interaktif dan gaya belajar adalah 0,507 dan koefisien pengaruh $\left(P_{21}\right)$ sebesar 0,203; serta koefisien korelasi antara gaya belajar dan prestasi belajar matematika adalah 0,316 dan koefisien pengaruh $\left(P_{42}\right)$ sebesar 0,326; thitung $=4,591>0,207$ dan sig 0,000 < 0,05, sehingga koefisien: $P_{21}$. $P_{42}=(0,203)(0,326)=0,066$. Jadi dapat disimpulkan: Terdapat beberapa hal yang dapat dijadikan indikasi bahwa pembelajaran yang dilakukan dengan multimedia interaktif dapat dikatakan efektif, antara lain ditandai dengan siswa paham terhadap materi matematika yang diajarkan, sikap positif siswa terhadap guru dan teman-temannya, dan keaktifan siswa pada saat pembelajaran matematika berlangsung. Oleh karena itu, dalam kegiatan belajar, siswa perlu dibantu dan diarahkan untuk mengenali gaya belajar yang sesuai dirinya sehingga tujuan pembelajaran matematika dapat dicapai secara efektif [16].

\section{Uji Hipotesis 8}

Koefisien korelasi antara gaya belajar dan Konsep diri adalah 0,507 dan koefisien pengaruh $\left(P_{32}\right)$ sebesar -0,010; serta koefisien korelasi antara Konsep diri dan prestasi belajar matematika adalah 0,273 dan koefisien pengaruh $\left(P_{43}\right)$ sebesar 0,149 ; thitung $=-1,018<0,207$ dan sig 0,003 $<0,05$, sehingga didapat koefisien: $P_{32} . P_{43}$ $=(-0,010)(0,149)=-0,001$. Dapat disimpulkan bahwa: Gaya belajar siswa dalam kegiatan kesehariannya secara tidak langsung dapat mempengaruhi prestasi belajar matematika, sehingga suasana pembelajaran matematika bisa berjalan dengan baik. Gaya belajar yang sesuai dengan siswa yang dapat membantu dalam memahami pengetahuan dan menyerap informasi. Gaya belajar yang buruk berpengaruh terhadap prestasi belajar siswa yang seyogyanya harus memiliki kompetensi mumpuni dalam bidangnya [3]. Siswa yang menganggap dirinya positif melakukan hal dengan hati-hati, mau mencoba mengatasi kesulitan yang dihadapi, sehingga akan bertambah kemungkinannya untuk sukses. Siswa yang mempunyai konsep diri yang tinggi akan menunjukkan tingkat aspirasi yang tinggi, optimis, percaya diri, realistis, mandiri, dan dapat menyesuaikan diri dengan baik [13].

\section{Uji Hipotesis 9}

Koefisien korelasi antara multimedia interaktif dan gaya belajar adalah 0,329 dan koefisien pengaruh $\left(P_{21}\right)$ sebesar 0,203; serta koefisien korelasi antara gaya belajar dan Konsep diri adalah 0,086 dan koefisien pengaruh $\left(P_{32}\right)$ sebesar $-0,010$ dan thitung $=2,427>0,207$ dan sig $0,001<$ 0.05; sehingga didapat koefisien: $P_{21} . P_{32}=$ $(0,203)(-0,010)=-0,002$. Dapat disimpulkan bahwa: Multimedia interaktif dalam pembelajaran adalah alat bantu pembelajaran matematika yang menggabungkan unsur pembentuk media, meliputi teks, audio, video yang memenuhi syarat tertentu untuk digunakan dalam proses pembelajaran. Terdapat banyak faktor yang mempengaruhi prestasi belajar matematika di antaranya kurangnya rasa percaya diri siswa pada akhirnya meruntuhkan keyakinan dan mengubah konsep diri. Dalam diri siswa terbentuk pemikiran bahwa bidang matematika bukanlah yang menyenangkan untuk dipelajari. Kondisi sebaliknya berlaku untuk siswa yang menyukai tantangan belajar. Matematika merupakan sebuah proses belajar yang sangat menarik dan penuh keunikan. Kondisi yang ada dan 
dimiliki akan memberi arah bagi sesesorang untuk menemukan gaya belajarnya dan selanjutnya membangun konsep diri sesuai dengan pemahaman atas dasar potensi yang dimiliki. Gaya belajar dipahami sebagai cara yang disukai oleh peserta didik dalam mengolah, mengatur, memahami, informasi yang diperoleh serta memecahkan permasalahan matematika yang dihadapi dalam aktivitas belajar dengan berinteraksi dan merespon lingkungan belajarnya [3]. Hal ini sesuai dengan penelitian mengatakan bahwa The rapid growth and adoption of education leads to a significant need for multimedia techniques and systems. Interaction between students between students and teachers because of the large volume of multimedia data. interactive multimedia system for learning with several new characteristics. First, a hierarchical structure for multimedia systems has been proposed to support learning styles and personalized self-concepts to enhance learning achievement [17]. Selain itu, [18] mengatakan the results showed that the data fit the model adequately for interactive learning strategies and selfconcept on student mathematics learning outcomes.

\section{SIMPULAN}

Hasil penelitian menunjukkan bahwa: 1) Multimedia interaktif berpengaruh positif dan signifikan terhadap gaya belajar. 2) Multimeda interaktif berpengaruh positif dan signifikan terhadap konsep diri, 3) Gaya belajar tidak berpengaruh signifikan terhadap konsep diri. 4) Gaya belajar berpengaruh positif dan signifikan terhadap prestasi belajar matematika. 5) Konsep diri berpengaruh positif dan signifikan terhadap prestasi belajar matematika. 6) Multimedia interaktif berpengaruh tidak langsung terhadap prestasi belajar matematika melalui konsep diri. 7) Multimedia interaktif berpengaruh tidak langsung dan signifikan terhadap prestasi belajar matematika melalui gaya belajar. 8) Gaya belajar tidak berpengaruh tidak langsung terhadap prestasi belajar matematika melalui konsep diri. 9) Multimedia interaktif tidak berpengaruh positif dan signifikan terhadap konsep diri melalui prestasi belajar matematika.

\section{DAFTAR PUSTAKA}

[1] R. E. Flora Siagian. "Pengaruh Minat dan Kebiasaan Belajar Siswa terhadap Prestasi Belajar Matematika". Form. J. Ilm. Pendidik. MIPA, vol. 2, no. 2, pp. 122-131 Aug. 2015.

[2] M. Cleopatra. "Pengaruh Gaya Hidup dan Motivasi Belajar terhadap Prestasi Belajar Matematika". Form. J. Ilm. Pendidik. MIPA, vol. 5, no. 2, pp. 168-181 Oct. 2015.

[3] I. R. Khoeron, N. Sumarna, dan T. Permana. "Pengaruh Gaya Belajar terhadap Prestasi Belajar Peserta Didik pada Mata Pelajaran Produktif". J. Mech. Eng. Educ., vol. 1, no. 2, p. 291, Sep. 2016.

[4] G. Gunawan, A. Harjono, dan I. Imran. "Pengaruh Multimedia Interaktif dan Gaya Belajar terhadap Penguasaan Konsep Siswa". J.Pendidik. Fis. Indones., vol. 12, no. 2, pp. 118-125, 2016.

[5] P. S. Utami dan A. Gafur. "Pengaruh Metode Pembelajaran dan Gaya Belajar Siswa terhadap Hasil Belajar IPS di SMP Negeri di Kota Yogyakarta". Harmon. Sos. J. Pendidik. IPS, vol. 2, no. 1, pp. 97103, Mar. 2015.

[6] M. Hidayah. "Pengaruh Konsep Diri dan Kecemasan Belajar terhadap Kemampuan Menyelesaikan Masalah Matematika pada Siswa Madrasah Aliyah Negeri di Jakarta Barat". $J$. Ilmu. Pendidikan. MIPA, vol. 5 no. 3 , pp. 268-278, 2016.

[7] Leonard dan Supardi US. "Pengaruh Konsep Diri, Sikap Siswa pada 
Matematika, dan Kecemasan Siswa terhadap Hasil Belajar Matematika". J. Cakrawala Pendidik, vol. 3, no. 3, pp. 341-351, 2010.

[8] A. R. Hakim dan H. Windayana. "Pengaruh Penggunaan Multimedia Interaktif dalam Pembelajaran Matematika untuk Meningkatkan Hasil Belajar Siswa SD”. EduHumaniora, J. Pendidik. Dasar Kampus Cibiru, vol. 4, no. 2, 2016.

[9] D. Novitasari. "Pengaruh Penggunaan Multimedia Interaktif terhadap Kemampuan Pemahaman Konsep Matematis Siswa”. Fibonacci J. Pendidik. Mat. dan Mat., vol. 2, no. 2, p. 8, 2016.

[10] H. Liberna. "Hubungan Gaya Belajar Visual dan Kecemasan Diri terhadap Pemahaman Konsep Matematika Siswa Kelas X SMK Negeri 41 Jakarta”. JNPM (Jurnal Nas. Pendidik. Mat., vol. 2, no. 1, p. 98, 2018.

[11] Bire A. L, Geradus. U, dan Bire Josua. "Pengaruh Gaya Belajar Visual, Auditorial, dan Kinestetik terhadap Prestasi Belajar Siswa". $J$. Kependidikan Penelit. Inov. Pembelajaran, vol. 44, no. 2, pp. 168-174, 2014.

[12] D. A. Nurhidayah. "Pengaruh Motivasi Berprestasi dan Gaya Belajar terhadap Prestasi Belajar Siswa pada Mata Pelajaran Matematika SMP". J. Dimens. Pendidik. dan Pembelajaran, vol. 12, no. 1, p. 53, 2015.
[13] N. Alamsyah. "Pengaruh Konsep Diri terhadap Prestasi Belajar Matematika Siswa SMAN 102 Jakarta". SAP (Susunan Artik. Pendidikan), vol. 1, no. 2, pp 155164, 2016.

[14] I. Magfirah, U. Rahman, and S. Sulasteri. "Pengaruh Konsep Diri dan Kebiasaan Belajar terhadap Hasil Belajar Matematika Siswa Kelas VIII SMP Negeri 6 Bontomatene Kepulauan Selayar". J. Mat. dan Pembelajaran, vol. 3, no. 3, pp. 103116, 2015.

[15] E. Irawan dan T. Suryo. "Implikasi Multimedia Interaktif Berbasis Flash terhadap Motivasi dan Prestasi Belajar Matematika". Beta J. Tadris Mat, vol. 10, no. 1, p. 33, 2017.

[16] Tiurma L dan Retnawati. "Keefektifan Pembelajaran Multimedia Materi Dimensi Tiga Ditinjau dari Prestasi dan Minat Belajar Matematika di SMA". $J$. Kependidikan Penelit. Inov. Pembelajaran, vol. 44, no.2, pp. 175187, 2014.

[17] Y. Liu and W. H. Chit. "Interactive Multimedia System for Distance Learning of Higher Education, vol. 3942, LNCS pp. 291-300, 2006.

[18] D. M. McInerney, R. W. yi Cheng, M. M. C. Mok, and A. K. H. Lam, "Academic Self-Concept and Learning Strategies: Direction of Effect on Student Academic Achievement". J. Adv. Acad., vol 23, no. 3, pp. 249-269, 2012. 